\title{
Pengaruh Penggunaan Webquiz Quizizz Terhadap Hasil Belajar Sosiologi Siswa di SMA N 16 Padang
}

\author{
Genta Cristiyanda ${ }^{1}$, Ike Sylvia ${ }^{2}$
}

${ }^{1,2}$ Universitas Negeri Padang

Email: gentaputrayanda@gmail.com ikesylvia@fis.unp.ac.id

\begin{abstract}
Abstrak
Penelitian ini bertujuan untuk mengetahui pengaruh penggunaan webquiz quizizz terhadap hasil belajar sosiologi siswa kelas XI di SMA Negeri 16 Padang, khususnya pada aspek pemahaman konsep siswa pada materi masalah sosial dalam masyarakat. Penelitian ini berjenis eksperimen dengan formula control group pretes-postes design. Teknik pengumpulan data melalui soal yang diberikan pada saat pretest dan posttets menggunakan aplikasi webquiz quizizz. Populasi pada penelitian ini adalah siswa kelas XI yang berjumlah 183 orang dengan teknik pengambilan sampel melalui random kelompok. Penelitian ini dianalisis dengan teori konstruktivistik yang dikemukakan oleh Piaget. Temuan penelitian terdapat pengaruh penggunaan web quizizz terhadap hasil belajar siswa khususnya pada materi masalah sosial pada pembelajaran sosiologi di kelas XI IPS 1 SMA N 16 Padang untuk materi pengertian masalah sosial, faktor pendorong masalah sosial, contoh masalah sosial dalam masyarakat, dampak masalah sosial dan pemecahan masalah sosial dalam masyarakat, hal ini dibuktikan dengan nilai t hitung $=6,34$ dengan taraf nyata 0,05 sedangkan tabel $=2,00$. Oleh karena $t$ hitung besar dari t tabel maka hipotesis penelitian diterima.
\end{abstract}

Kata kunci: Pemahaman konsep, Pembelajaran Sosiologi, Webquiz Quizizz.

\section{Abstract}

This study aims to determine the effect of using webquiz quizzes on sociology learning outcomes of class XI students at SMA Negeri 16 Padang, especially in the aspect of understanding the concept of students on material social problems in society. This research is an experimental type of research with a pretest-posttest control group design formula. Data collection techniques through the questions given during the pretest and posttets using the quizizz web quiz application. The population in this study were 183 class XI students with a random group sampling technique. This research was analyzed by using the constructivist theory proposed by Piaget. The findings of the study are the influence of the use of web quizzes on student learning outcomes, especially on social problem material on sociology learning in class XI IPS 1 SMA N 16 Padang for understanding social problems, driving factors of social problems, examples of social problems in society, the impact of social problems and solving social problems in society, this is evidenced by the value of t count $=6.34$ with a real level of 0.05 while the table $=2.00$. Because $t$ is large from $t$ table, the research hypothesis is accepted.

Keywords: Concept understanding, Sociology Learning, Webquiz Quizizz.

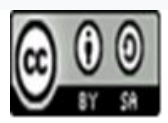

Received: January 20, 2021 Revised: February 11, 2021 Accepted: February 12, 2021 


\section{Pendahuluan}

Aset terpenting dari setiap bangsa ialah sumber daya manusia.'Kesiapan sumber daya alam yang banyak serta terdapatnya sumber 'daya modal serta teknologi yang makin maju, tidak memiliki kontribusi yang bernilai tambah, tanpa didukung sumber daya manusia (human resources) yang bermutu.'Oleh karena itu, kenaikan mutu bangsa sebetulnya bertumpu pada kenaikan mutu'sumber manusianya, serta semua itu dapat diraih dengan mengedepankan makna pendidikan.'Pendidikan adalah hal pokok dalam berkembangnya bangsa tersebut. Kemajuan suatu bangsa diukur dari kualitas dan sistem pendidikan yang ada. Tanpa pendidikan, suatu negara akan jauh tertinggal dengan negara lain (Sari, Erianjoni, \& Sylvia, 2019).'Artinya pendidikan sangat penting dalam meningkatkan mutu suatu bangsa.'

Keberhasilan proses pendidikan pembelajaran tidak terlepas dari bagaimana proses perencanaan, implementasi serta kebijakan penunjang yang dilakukan secara berkesinambungan. Karena pendidikan adalah modal dasar pembangunan maka setiap negara sudah barang tentu menempatkannya pada tujuan utama. Hal ini juga sesuai dengan tujuan terbentuknya Negara Kesatuan Republik Indonesia yang akhirnya tertuang dalam pembukaan UUD 1945 alenia IV, diantaranya adaIah "Mencerdaskan Kehidupan Bangsa". Karena para founding fathers sadar bahwa pendidikan adalah sarana utama dalam mengubah peradaban bangsa ke arah yang Iebih baik (Santika, 2020). Pada kegiatan pendidikan, sangat erat hubungannya dengan pelaksanaan pembelajaran. Pembelajaran adalah setiap kegiatan yang dirancang oleh guru untuk membantu seseorang mempelajari kemampuan dan atau nilai baru dalam suatu proses yang sistematis melalui tahap rancangan, pelaksanaan, dan evaluasi dalam konteks kegiatan belajar'mengajar. Secara sederhana strategi pembelajaran adalah taktik yang harus direncanakan guru untuk mencapai tujuan pembelajaran yang telah ditetapkan (Susanti \& Junaidi, 2020).

Guru pada dasarnya memiliki tugas seperti mengajar, mendidik, mengarahkan, membimbing, menilai, melatih, mengevaluasi/siswa didik dan juga guru sebagai pemberi motivasi kepada siswanya. Pada proses pembelajaran terjadinya stimulus respon berupa pesan dari guru kepada siswa, sumber pesan salah satunya adalah guru dan pesan yang disampaikan berupa materi pembelajaran yang akan diajarkan serta media adalah alat bantu atau alat peraga yang digunakan guru untuk menyampaikan materi pembelajaran.'

Dewasa ini bidang pendidikan telah banyak dipengaruhi oleh adanya perkembangan dan penemuan-penemuan dalam bidang keterampilan, ilmu, dan teknologi. Pengaruh tersebut tampak jelas dalam upaya-upaya pembaharuan sistem pendidikan dan pembelajaran. Upaya pembaharuan tersebut tidak hanya menyentuh sarana fisik atau fasilitas pendidikan saja, tetapi juga sarana nonfisik seperti sarana pengembangan kualitas tenaga-tenaga kependidikan yang memiliki pengetahuan, kemampuan, dan keterampilan memanfaatkan fasilitas yang tersedia, cara kerja yang inovatif, serta sikap positif terhadap tugas-tugas kependidikan yang diembannya. (Azhar, 2011).

SMA N 16 Padang salah satu sekolah yang memiliki fasilitas pendidikan tergolong lengkap, diantaranya adanya perpustakaan, setiap kelas memiliki infokus, komputer, speaker, dan guru-guru telah memiliki laptop, serta ada juga tersedianya wifi di sekolah. Dengan adanya berbagai fasilitas pendidikan tersebut diharapkan dapat meningkatkan pemahaman siswa terhadap materi pelajaran dalam proses pembelajaran. Berdasarkan hasil wawancara peneliti dengan guru sosiologi Ibu LL pada tanggal 13 September 2020 di SMA N 16 Padang, guru menyatakan bahan ajar, media pembelajaran dan LKPD sudah dirancang oleh guru agar dapat disesuaikan untuk dapat digunakan dalam pembelajaran daring pada semester Juli - Desember 2020. Pembelajaran sosiologi memiliki dimensi konseptual dan sekaligus praktis serta memperkuat komitmen nilai. Tujuan pembelajaran sosiologi adalah untuk menumbuhkan kualitas berpikir yang mampu mendorong keterlibatan peserta didik dalam dunia publik. Dengan kata lain, pembelajaran sosiologi mementingkan penguasaan pengetahuan, nilai kemanusiaan dan keterlibatan sosial. (RI, 2016).

Jurnal Sikola: Jurnal Kajian Pendidikan dan Pembelajaran Vol. 2, No. 3, Th. 2021 
Dari cakupan, tujuan dan materi pembelajaran sosiologi di atas, maka dapat disimpulkan bahwa, idealnya dalam pembelajaran sosiologi siswa diharapkan mampu memahami konsep tentang materi pelajaran sosiologi dan mengaitkannya dengan fenomena yang terjadi dalam kehidupanya sehari-hari. Siswa diharapkan menelaah secara rasional masalah-masalah yang muncul serta mampu menemukan solusinya. Sehingga nantinya akan berpengaruh terhadap hasil belajar yang dicapainya. Menurut Sudjana (Sudjana, 2002) pemahaman merupakan kemampuan berpikir yang lebih tinggi dari hanya sekedar mengetahui. Dari pendapat ahli tersebut dapat dipahami bahwa pemahaman konsep merupakan kemampuan siswa mengungkap kembali konsep-konsep yang dipelajari baik lisan maupun tulisan, mampu menjelaskan, menyimpulkan dan mampu memberi contoh konsep-konsep yang ada pada materi pelajaran.

Pada observasi awal yang dilakukan pada pembelajaran sosiologi yang dilaksanakan secara daring dan hasil belajar yang diperoleh oleh siswa di kelas XI IPA 1 SMA N 16 Padang menunjukan hanya 1 orang siswa yang memperoleh ketuntasan dengan nilai 96 dari 38 orang siswa sedangkan 35 orang siswa lainnya dengan nilai di bawah KKM 78. Hasil ini menunjukkan belum efektifnya proses pembelajaran sosiologi pada KD 3.1. yang dilaksanakan secara daring pada bulan Juli - Agustus 2020. Hasil yang diperoleh ini menunjukkan rendahnya pemahaman dan penguasaan konsep materi siswa. Berdasarkan hasil studi dokumentasi yang peneliti lakukan dari buku nilai yang dimiliki oleh salah seorang guru mata pelajaran sosiologi di SMA Negeri 13 Padang kelas XI (Ibu LL, pada 29/09/2020), ditemukan nilai ujian tengah semester sosiologi siswa kelas XI masih dibawah kriteria ketuntasan minimal (KKM) yang telah ditetapkan yaitu di bawah 78, seperti yang tercantum dalam tabel 1 berikut:

Tabel 1. Rata-Rata Nilai Ujian Tengah Sosiologi Siswa Kelas XI pada Semester I SMAN 16 Padang Tahun Pelajaran 2020 - 2021

\begin{tabular}{clccc}
\hline No & Kelas & Jumlah Siswa & KKM & Nilai Rata-rata \\
\hline $\mathbf{1}$ & X1 IPS 1 & 38 & 78 & 65,25 \\
\hline $\mathbf{2}$ & X1 IPS 2 & 36 & 78 & 67,23 \\
\hline $\mathbf{3}$ & X1 IPS 3 & 37 & 78 & 65,30 \\
\hline $\mathbf{4}$ & X1 IPS 4 & 36 & 78 & 66,54 \\
\hline $\mathbf{5}$ & X1 IPS 5 & 36 & 78 & 66,30 \\
\hline & Jumlah & $\mathbf{1 8 3}$ & Rata-rata &
\end{tabular}

Sumber: Data Nilai UTS Peserta Didik Semester Juli - Desember 2020 di SMAN 16 Padang

Data di atas memperlihatkan rendahnya pengusaan materi peserta didik selama proses pembelajaran daring pada semester UTS Juli - Desember 2020. Berikut ini peneliti memaparkan data analisis terkaita jawaban peserta didik terhadap soal ujian tengah semester tersebut.

Tabel 2. Jumlah Persentase Jawaban Benar Ujian Tengah Semester Sosiologi Siswa Kelas XI Semester I SMA N 16 Padang Tahun Ajaran 2020-2021

\begin{tabular}{|c|c|c|c|c|c|c|c|c|}
\hline \multirow[b]{2}{*}{ No } & \multirow[b]{2}{*}{ Kelas } & \multicolumn{2}{|c|}{ Fakta } & \multicolumn{2}{|c|}{ Konsep } & \multicolumn{2}{|c|}{ Prinsip } & \multirow[b]{2}{*}{ Jumlah } \\
\hline & & $\begin{array}{c}\% \\
\text { Benar }\end{array}$ & $\begin{array}{c}\% \\
\text { Salah }\end{array}$ & $\begin{array}{c}\% \\
\text { Benar }\end{array}$ & $\begin{array}{c}\% \\
\text { Salah }\end{array}$ & $\begin{array}{c}\% \\
\text { Benar }\end{array}$ & $\begin{array}{c}\% \\
\text { Salah }\end{array}$ & \\
\hline 1 & X1 IPS 1 & 63,50 & 36,50 & 51,27 & 48,72 & 39,43 & 60,57 & \multirow{5}{*}{$\begin{array}{l}\text { Soal Fakta }=11 \\
\text { Soal Konsep }=21 \\
\text { Soal Prinsip }=8\end{array}$} \\
\hline 2 & X1 IPS 2 & 60,58 & 39,42 & 36,59 & 63,4 & 64,43 & 35,57 & \\
\hline 3 & X1 IPS 3 & 50,69 & 49,31 & 43,37 & 56,62 & 50,69 & 49,31 & \\
\hline 4 & X1 IPS 4 & 55,65 & 44,35 & 37,24 & 62,75 & 40,53 & 59,47 & \\
\hline 5 & X1 IPS 5 & 63,52 & 36,48 & 37,24 & 62,75 & 42,32 & 57,68 & \\
\hline
\end{tabular}

Sumber: Data Primer 2020 
Berdasarkan data pada tabel 2, terlihat bahwa nilai ujian tengah semester genap kelas XI SMAN 16 Padang tahun ajaran 2020-2021 masih banyak siswa yang belum mampu menjawab soal dalam kategori konsep, sehingga menyebabkan rendahnya hasil belajar siswa. Dari data di atas terlihat bahwa kurangnya pemahaman konsep siswa terhadap materi sosiologi. Seharusnya siswa yang paham terhadap sesuatu mampu menjelaskan, mengklasifikasikan dan mengutarakannya dengan bahasa sendiri. Pada umumnya siswa memberikan penjelasan berdasarkan penjelasan yang ada pada buku. Hal ini disebabkan oleh pembelajaran yang hanya membiasakan siswa dengan pemberian pengetahuan, semua didominasi oleh guru melalui metode ceramah dan mengandalkan media cetak saja serta guru cenderung mengambil contoh dari buku paket dan tidak dibiasakan siswa menemukan sendiri contoh-contoh yang berkaitan dengan materi pelajaran.

Menurut Slameto (Slameto, 2010) ada faktor-faktor yang mempengaruhi belajar siswa yaitu faktor internal dan faktor eksternal. Faktor internal yang berasal dari dalam diri siswa seperti faktor jasmaniah, psikologis (minat, motivasi, intelegensi dan bakat) tingkah laku terjadi tanpa dipengaruhi oleh faktor lingkungan, individu bertingkah laku karena mendapatkan energi atau terdorong untuk bertingkah laku. Sedangkan faktor eksternal siswa merupakan faktor yang berada diluar diri individu berpengaruh besar terhadap seseorang, secara keseluruhan faktor eksternal yaitu faktor keluarga, faktor sekolah seperti metode mengajar, kurikulum, relasi guru dengan siswa, disiplin, alat pelajaran serta keadaan gedung. Faktor eksternal lain yaitu masyarakat. Untuk mengatasi hal tersebut perlu dirancang proses pembelajaran dan penilaian agar siswa terlibat aktif daIam pembelajaran sosiologi. "Keterlibatan aktif siswa dalam belajar akan berkaitan dengan peran guru yang mana guru harus"menyesuaikan kegiatan belajar dengan perkembangan teknologi"saat ini."Pendidik/guru hendaknya mengadopsi gaya/model belajar yang bisa memotivasi siswa agar berpartisipasi pada proses belajar di kelas.(Robert E. Slavin, 2006). Partisipasi siswa dalam diharapkan dapat meningkatkan penguasaan materisiswa. Keberhasilan proses pembelajaran terletak pada turut sertanya peserta didik/siswa secara aktif. Selanjutnya apapun metode atau model yang digunakan dalam proses pembelajaran harus memungkinkan peserta didik/siswa dapat belajar secara aktif. (Lickona, 1991). Agar upaya peningkatan kualitas pembelajaran dapat dilakukan, terlebih dahulu dibenahi model atau metode pembeIajaran yang digunakan sehingga model atau metode pembelajaran yang digunakan sesuai dan ber variasi daIam proses pembelajaran. (Santrock, 2011).

Salah satu bagian integral dari upaya pembaharuan itu adalah media pembelajaran. Heinich, dkk (Heinich, R. Molenda, M., Russell, J.D, Smaldino, 2002) mengemukakan media adalah perantara yang mengantar informasi antara sumber dan penerima. Selanjutnya menurut (David A Payne, 1994) mengartikan media pembelajaran merupakan seperangkat alat bantu atau perlengkapan yang digunakan oleh pendidik dalam rangka berkomunikasi dengan peserta didik. Jadi media merupakan salah satu perantara yang digunakan guru untuk berkomunikasi dalam proses pembelajaran.

Media pembelajaran merupakan sarana yang efektif dalam membantu pendidik/guru agar pembelajaran berjalan lancar. Alat peraga/alat bantu yang digunakan guru bertujuan agar bisa meningkatkan motivasi siswa serta bisa meningkatkan penguasaan konsep siswa terhadap materi sosiologi. Perkembangan teknologi digital di era Industri 4.0 saat ini telah membawa perubahan dan mempengaruhi berbagai aspek kehidupan manusia, termasuk di bidang pendidikan (Putrawangsa \& Hasanah, 2018). Revolusi industri generasi ke empat (4.0) memiliki ciri khas berkembangnya teknologi yang semakin mutakhir, selain itu juga memiliki tantangan dan permasalahan. Salah satu tantangan yang harus dihadapi adalah perbaikan sektor Sumber Daya Manusia (SDM) yang dapat diantisipasi meIalui peningkatan kualitas pendidikan. Hal yang paling fundamental adalah mengubah pola pikir dan sifat peserta didik/siswa daIam mengembangkan kemampuannya daIam menghadapi revoIusi industri 4.0 sehingga dapat menjadi sumber daya manusia yang unggul. Untuk itu, ada kecakapan yang harus dimiliki oleh 
setiap individu agar tetap bersaing dan diperhitungkan daIam kehidupan pada abad ke-2, yaitu, (1) critical thinking and problem solving, (2) collaboration, (3) good communication, (4) creative and innovative thinking skiII, (5) social responsibility, (6) work ethic. (Sylvia, Anwar, \& Khairani, 2019)

Perkembangan teknologi serta ilmu pengetahuan sudah mempengaruhi pemakaian alat/sarana di sekolah serta lembaga Pendidikan lainnya. Dewasa ini pembelajaran di sekolah mulai disesuaikan dengan perkembangan teknologi informasi, sehingga terjadi perubahan dan pergeseran paradigma pendidikan (Muhson, 2010)."'HaI"tersebut menandakan bahwa pemanfaatan teknologi informasi dalam"pembelajaran di kelas, telah menjadi"kebutuhan serta tuntutan dunia modern"ini. Teknologi merupakan alat, sarana serta bisa juga sebagai instrumen penilaian yang dapat menunjang meningkatnya keaktifan siswa dalam proses pembelajaran."Pada era modern saat ini yang mana teknologi makin maju sehingga bermunculan beragam aplikasi"pengolah instrumen penilaian berbasis website yang membantu mempermudahkan guru hingga bisa membuat dan"mengolah instrumen penilaiannya dengan bantuan web tersebut. (Darling-Hammond, 2014) 'Aplikasi web yang bisa dipergunakankan untuk membuat alat penilaian ialah Webquiz Quizizz. Quizizz adalah web program yang memberikan kemudahan bagi pengajar untuk membuat alat evaluasi dengan bentuk kuis. Dalam pembelajaran Webquiz Quizizz dapat diaplikasikan untuk melakukan penilaian penguasaan materi siswa serta sekaligus meningkatkan motivasi siswa dalam belajar. Instrumen penilaian bentuk kuis ini bisa diaplikasikan pada proses pembelajaran berlangsung.'

\section{Metode Penelitian}

Penelitian ini menggunakan pendekatan kuantitatif tipe penelitian eksperimen dengan desain penelitian formula control group pretes-postes design. Pendekatan ini dipilih bertujuan untuk mengetahui pengaruh penggunaan webquiz quizizz terhadap motivasi belajar siswa SMA N 16 Padang. Dengan rancangan seperti tabel di bawah ini:

Tabel 3. Rancangan Penelitian

\begin{tabular}{cccc}
\hline Kelas & Tes Awal & Perlakuan & Tes Akhir \\
\hline $\mathrm{R}$ & $\mathrm{O} 1$ & $\mathrm{X}$ & $\mathrm{O} 2$ \\
\hline $\mathrm{R}$ & $\mathrm{O} 3$ & & $\mathrm{O} 4$ \\
\hline
\end{tabular}

(Sugiyono, 2008)

Sesuai dengan fokus kajian, populasi dalam penelitian ini adalah seluruh siswa kelas XI IPS SMAN 16 Padang yang berjumlah 183 orang. Pengambilan sampel dilakukan dengan random kelompok, sehingga terpilih kelas XI IPS 1 sebagai kelas eksperimen yang berjumlah 38 orang dan kelas XI IPS 2 yang berjumlah 36 orang. Pemilihan kelas ini didasarkan pada nilai yang diperoleh dari UH 1 dan ujian tengah semester peserta didik di kelas tersebut.

Teknik pengumpulan data pada penelitian ini melalui data primer yaitu data yang diperoleh dari dapat dari siswa kelas XI SMAN 16 Padang dan data sekunder yaitu data yang didapat melalui tata usaha dan wakil kepala sekolah. Instrumen penelitian yang digunakan adalah berbentuk tes yang dilakukan sebanyak dua kali (pretest dan postest) melalui aplikasi webquiz quizizz dengan soal berbentuk pilihan ganda. Uji validitas soal dilakukan dengan menggunakan rumus r-product moment. Uji validitas dilakukan untuk melihat apakah soal pretes itu valid atau tidak. Apabila $r$ hitung lebih kecil dari $r$ tabel maka soal dinyatakan tidak valid, dan sebaliknya, apabila $\mathrm{r}$ hitung lebih besar dari $\mathrm{r}$ tabel maka soal berarti valid. Berdasarkan hasil uji validitas pada soal konsep dari 36 soal ada 6 soal yang tidak valid sehingga soal yang daapt diujicobakan berjumlah 30 soal. Uji normalitas dilakukan untuk melihat apakah sampel berasal dari populasi yang distribusi normal. Berdasarkan hasil uji normalitas pada kelas ekperimen Lo $=0,1324$ dan kelas kontrol Lo $=0,1514$ sedangkan L tabel $=0,1618$, ini berarti Lo

Jurnal Sikola: Jurnal Kajian Pendidikan dan Pembelajaran Vol. 2, No. 3, Th. 2021 
$<$ L tabel, maka data pada kelas eksperimen dan keals kontrol terdistribusi normal. Sedangkan uji homogenitas bertujuan untuk melihat apakah kedua sampel mempunyai varians yang homogen atau tidak. Berdasarkan analisis data hasil uji homogenitas pada kelas eksperimen dan kelas kontrol didapat $\mathrm{F}$ hitung=1,82, sedangkan $\mathrm{F}$ tabel= 1,85 , maka ke dua kelas sampel mempunyai varians yang homogen.

Setelah melakukan uji normalitas dan uji homogenitas maka ditetapkan statistik uji hipotesis. Uji hipotesis bertujuan untuk mengetahui apakah terdapat pengaruh penggunaan webquiz quizizz terhadap hasil belajar siswa SMA N 16 Padang. Kriteria pengujian hipotesis adalah jika t hitung sama dengan atau lebih besar dari nilai t pada tabel maka hipotesis nol (Ho ditolak), jika t hitung lebih kecil dari nilai t pada tabel maka hipotesis nol (Ho diterima). Pengolahan data melalui perhitungan statistik dengan tingkat kepercayaan $(\alpha=0,05)$.

\section{Hasil dan Pembahasan}

Hasil belajar adalah kemampuan-kemampuan yang dimiliki siswa setelah ia menerima pengalaman (Sudjana, 2002). Kemampuan yang dimiliki siswa tersebut penerimaan dan dapat diulang-ulang dengan hasil belajar yang sama. Hasil belajar dapat dijadikan tolak ukur menentukan tingkat keberhasilan siswa. Khusus pada penelitian ini, hasil belajar yang akan diteliti adalah pada ranah kognitif yang berupa tes belajar. Hasil belajar siswa ini, dapat dilihat setelah diberikan tes pada kelas sampel sesuai dengan materi yang telah dipelajari selama penelitian berlangsung.

Menurut Sudjana (Sudjana, 2002) Pemahaman adalah kemampuan berfikir yang lebih tinggi dari hanya sekedar mengetahui. Selanjutnya menurut A Muri Yusuf (Yusuf, 2015) pemahaman adalah kemampuan seseorang untuk mengerti atau memahami sesuatu setelah sesuatu itu diketahui dan diingat. Dengan kata lain, memahami adalah mengetahui tentang sesuatu dan dapat melihatnya dari berbagai segi. Seseorang siswa dikatakan memahami sesuatu apabila ia dapat memberikan penjelasan atau uraian yang lebih rinci tentang hal itu dengan menggunakan kata-katanya sendiri.

Pada hakikatnya kegiatan belajar mengajar adalah suatu proses komunikasi. Proses komunikasi (proses penyampaian pesan) tercipta melalui kegiatan penyampaian pesan atau informasi oleh guru kepada peserta didik. Penggunaan penggunaan webquiz quizizz dalam pembelajaran sosiologi di kelas XI SMA N 16 Padang didesain agar siswa dapat memahami materi masalah sosial sehingga akan membangun pengetahuan mereka dalam proses pembelajaran.

Setelah melakukan penelitian pada kedua kelas sampel, diperoleh data tentang hasil belajar siswa. Untuk melihat tercapainya tujuan pembelajaran, peneliti melakukan tes pada dua kelas, yaitu kelas eksperimen XI IPS 1 dan kelas kontrol XI IPS 2. Jumlah siswa kelas eksperimen 38orang dan kelas kontrol 36 orang.

Dalam penelitian ini peneliti tidak melakukan uji coba soal, sebab pada saat peneliti akan melakukan penelitian semua siswa belum mempelajari materi masalah sosial, sehingga yang dilakukan adalah analisis butir soal pada lembar jawaban posttest kelas eksperimen.

Pada analisis pretest kelas eksperimen dan kontrol diketahui bahwa tidak ada perbedaan antara kelas eksperimen dan kelas kontrol, hal ini diketahui dari hasil uji t, pada perhitungan uji $t$ pretest diproleh $\mathrm{t}$ hitung $=0,96$ dengan dengan taraf nyata $\alpha=0,05$ dan didapat $\mathrm{t}$ tabel 2,00, berarti $t$ hitung kecil dari t tabel. Berdasarkan uji pretest tersebut peneliti melakukan analisis data skor posttest dalam uji hipotesis.

Berdasarkan hasil analisis data posttest kelas eksperimen menggambarkan bahwa, pembelajaran dengan penggunaaan webquiz quizizz dalam pembelajaran sosiologi di kelas XI SMA N 16 Padang didesain agar siswa dapat memahami materi masalah sosial berpengaruh terhadap pemahaman konsep peserta didik. Tercapainya tujuan pembelajaran dapat dilihat dari

Jurnal Sikola: Jurnal Kajian Pendidikan dan Pembelajaran Vol. 2, No. 3, Th. 2021 
deskripsi data yang diperoleh melalui tes akhir yang dilakukan pada akhir pembelajaran. Dari tes akhir tersebut diperoleh rata-rata skor hasil belajar dari 30 soal konsep untuk materi masalah sosial pada kelas eksperimen adalah 19,53 sedangkan pada kelas kontrol adalah 16,13. Rata-rata kelas eksperimen lebih tinggi dari rata-rata kelas kontrol. Selain itu juga dapat juga dilihat dari uji t yang telah dilakukan. Berdasarkan uji $t$ diperoleh nilai t hitung $=6,34$ dengan taraf nyata 0,05 sedangkan tabel $=2,00$. Oleh karena t hitung besar dari t tabel maka hipotesis penelitian diterima.

Pada sisi lain dapat juga dilihat perbandingan sebaran skor nilai posttest kelas eksperimen dan kelas kontrol, ternyata pada kelas eksperimen kecendrungan data (varians) kelas eksperimen lebih homogen dibanding kelas kontrol, persebaran skor kelas eksperimen dan kelas kontrol dapat dilihat pada grafik berikut:

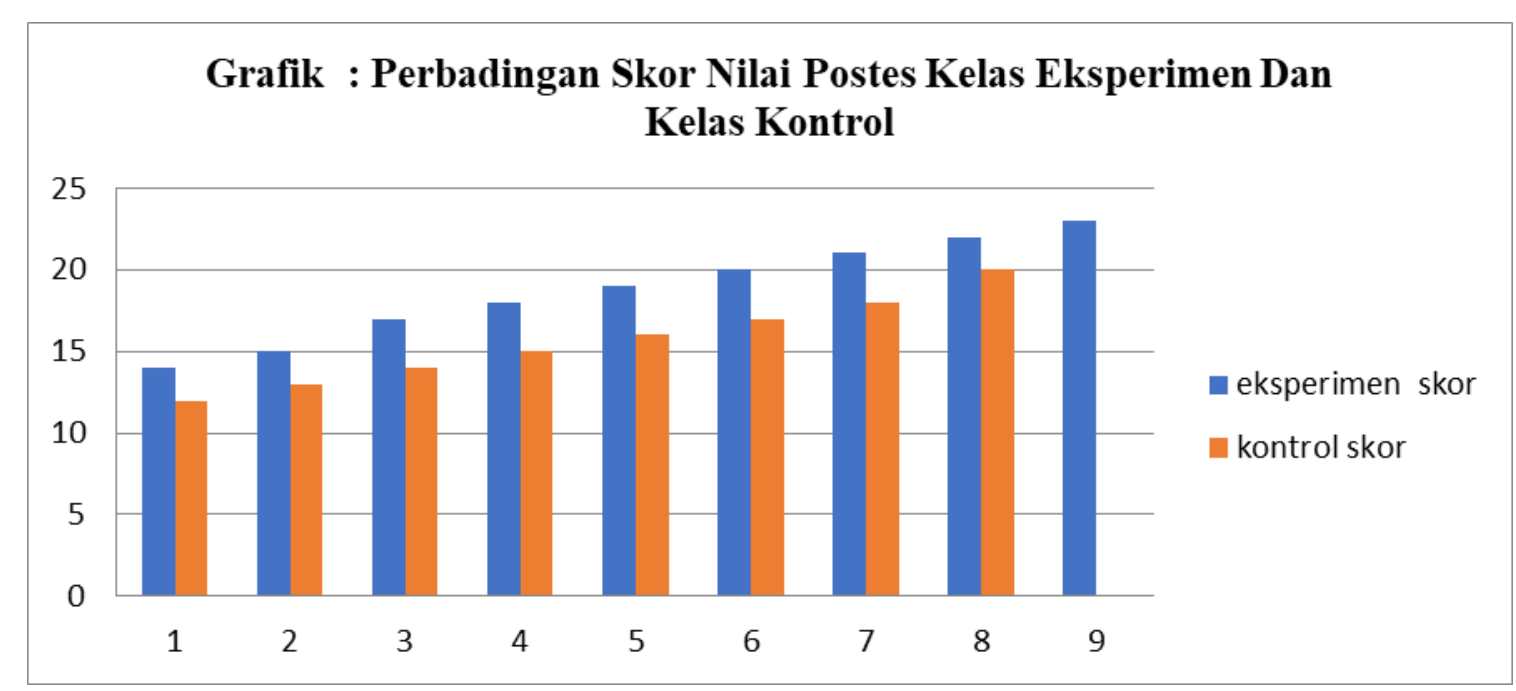

Gambar 1. Grafik Perbandingan Skor Nilai Postes Kelas Eksperimen dan Kelas Kontrol Sumber: diolah dari data primer penelitian 2020

Dari deskripsi data penelitian didapat bahwa rata-rata kelas eksperimen lebih tinggi dibandingkan kelas kontrol. Pembelajaran dengan menggunakan webquiz quizizz dalam pembelajaran sosiologi di kelas XI SMA N 16 Padang pada materi masalah sosial seperti yang dikemukakan oleh Piaget bahwa konstruktivisme merupakan suatu proses dimana anak secara aktif membangun sistem arti dan pemahaman terhadap realita melalui pengalaman dan interaksi mereka, arti kata proses pembelajaran tidak lagi berpusat pada guru. Guru sebagai fasilitator harus mampu menerapkan suasana belajar yang melibatkan siswa secara aktif dalam proses pembelajaran. Siswa akan aktif berada dalam pembelajaran yang bisa membuat siswa bisa melakukan aktivitas seperti berbicara, mengungkapkan pendapat, membaca, menulis dan saling berhubungan dengan siswa lain dan juga guru.

Untuk memahami suatu konsep, seseorang harus menggunakan sebanyak mungkin indranya. Oleh karena itu, dalam pembelajaran penggunaan webquiz quizizz berbasis presentasi soal sangat menarik, karena memiliki kombinasi antara teks, gambar, animasi dan suara, dapat membuat siswa mengkombinasikan alat inderanya untuk menjawab soal. Telinga digunakan untuk mendengarkan penjelasan soal yang ada pada webquiz quizizz, juga menggunakan indera mata untuk melihat fakta dari materi yang dipelajari ada pada webquiz quizizz, yang secara tidak langsung bisa mewadahi siswa yang mempunyai variasi dalam belajar. Dengan demikian semakin banyak indera yang digunakan siswa dalam proses pembelajaran semakin banyak pula materi yang pelajari bisa bertahan dalam memori siswa. 
Berdasarkan deskripsi data yang dilakukan secara terpisah guna untuk melihat apakah tiaptiap komponen pemahaman konsep signifikan. Ternyata, baik untuk kelompok soal pengertian masalah sosial, faktor penyebab masalah sosial, contoh masalah sosial di masyarakat, dampak masalah sosial, pemecahan masalah sosial terbukti dari hasil uji hipotesis nilai posttest kelas eksperimen dan kelas kontrol pada setiap sub pokok materi sosialisasi yang secara keseluruhan berbeda dibandingkan kelas kontrol, hal ini disebabkan pada kelas eksperimen pembelajaran diberi perlakuan dengan menggunakan soal pada webquiz quizizz, sedangkan pada kelas kontrol dengan soal biasa melalui aplikasi google formulir.

Untuk melihat pencapaian hasil belajar sosiologi dalam pemahaman konsep siswa, dapat dilihat dengan menggunakan uji t yang dilakukan pada setiap indikator materi sosialisasi, dapat dilihat pada tabel 4 berikut:

\section{Tabel 4. Hasil Uji T Setiap Komponen Indikator Materi Masalah Sosial}

\begin{tabular}{clcccc}
\hline No & \multicolumn{1}{c}{ Indikator } & T Hitung & T Tabel & Syarat & Keterangan \\
\hline 1 & $\begin{array}{l}\text { Pengertian Masalah } \\
\text { Sosial }\end{array}$ & 3,25 & 2,000 & $\begin{array}{c}\text { T hit }>\mathrm{T} \\
\text { tabel }\end{array}$ & Diterima \\
\hline 2 & $\begin{array}{l}\text { Faktor Penyebab } \\
\text { Masalah Sosial }\end{array}$ & 2,313 & 2,000 & $\begin{array}{c}\mathrm{T} \text { hit }>\mathrm{T} \\
\text { tabel }\end{array}$ & Diterima \\
\hline 3 & $\begin{array}{l}\text { Contoh Masalah Sosial } \\
\text { di Masyarakat }\end{array}$ & 2,19 & 2,000 & $\begin{array}{c}\mathrm{T} \text { hit }>\mathrm{T} \\
\text { tabel }\end{array}$ & Diterima \\
\hline 4 & $\begin{array}{l}\text { Dampak Masalah } \\
\text { Sosial }\end{array}$ & 2,26 & 2,000 & $\begin{array}{c}\mathrm{T} \text { hit }>\mathrm{T} \\
\text { tabel }\end{array}$ & Diterima \\
\hline 5 & $\begin{array}{l}\text { Pemecahan Masalah } \\
\text { Sosial }\end{array}$ & 2,095 & 2,000 & $\begin{array}{c}\mathrm{T} \text { hit }>\mathrm{T} \\
\text { tabel }\end{array}$ & Diterima \\
\hline
\end{tabular}

Dengan menggunakan soal melalui webquiz quizizz dalam pembelajaran sosiologi materi masalah sosial, semua indikator soal yang telah dirancang di awal proses pembelajaran dapat tercapai. Penggunaan webquiz quizizz dalam pembelajaran sosiologi materi masalah sosial berpengaruh terhadap hasil belajar peserta didik di kelas XI IPS1. Penggunaan webquiz quizizz dalam pembelajaran sosiologi materi masalah sosial dengan berbagai variasi suara, gambar, animasi, warna, huruf, video membuat siswa memahami materi dari informasi yang diperoleh, terjadi proses penyimpanan informasi dari tampilan materi pada webquiz quizizz interaktif berbasis multimedia, sehingga mereka mampu mengingat kembali materi yang diajarkan, melakukan generalisasi dan terjadinya umpan balik pada proses pembelajaran dengan metode tanya jawab. Sehingga siswa tidak hanya tahu konsep materinya saja, tetapi melalui fakta-fakta itulah siswa dilatih untuk berpikir mencari jawaban dari pertanyaan yang diberikan guru mengenai materi yang dipelajari. Dengan dibiasakannya siswa melaksanakan pembelajaran seperti ini pola pikir siswa lebih berkembang.

Adapun kelebihan pembelajaran dengan memberikan soal dengan variasi multimedia ini adalah soal menjadi lebih menarik, fakta dari fenomena social tergambar jelas, siswa menjadi antusias menjawab karena ada penghargaan untuksiswa terbaik, dilain waktu siswa daapt mengulang mencari jawabannya Kembali, membuat mereka antusias mengikuti pelajaran, karena dengan tampilan gambar-gambar fakta pada media interaktif akan menarik perhatian siswa, yang secara tidak langsung menimbulkan minat dan motivasi belajar siswa. Adapun kelemahan dari penggunaan webquiz quizizz guru tidak mengetahui secara pasti apakah peserta didik bekerja sendiri atau mencari bantuan. Namun kekurangan ini bisa diatasi dengan melakukan setelan waktu pada aplikas webquiz quizizz.

Terdapat perbedaan hasil belajar antara kelas eksperimen dan kelas kontrol dalam pencapaian hasil belajar. Hal ini disebabkan tidak adanya pemberian perlakuan webquiz quizizz 
pada proses pembelajaran pada kelas control membuat siswa kesulitan dalam memahami pelajaran terutama untuk menjelaskan konsep dan mengaitkannya dengan fakta-fakta yang ada dalam masyarakat, selain itu mereka terbiasa belajar pada buku sumber yang telah disediakan, sehingga mereka hanya bisa mengungkapkan kembali apa yang ada dalam buku tersebut. Siswa lebih senang mencatat materi pelajaran yang diberikan guru dan menerima apa yang disampaikan guru. Akibatnya materi yang dipelajari cepat hilang dari ingatan siswa karena tidak dipahami dan hasil belajar pun kurang optimal. Soal yang diberikan tidak bisa menjadi Latihan yang menarik bagi siswa sehingga mereka giat untuk mengulang Kembali seperti yang ada pada aplikasi webquiz quizizz.

Untuk memahami hasil penelitian ini dapat dijelaskan dengan menggunakan teori konstruktivistik yang dikemukakan oleh Piaget yang menekankan bahwa pengetahuan adalah konstruksi (bentukan) sendiri dan serta perkembangan kognitif merupakan suatu proses dimana anak secara aktif membangun sistem arti dan pemahaman terhadap realita melalui pengalaman dan interaksi mereka, arti kata proses pembelajaran tidak lagi berpusat pada guru. Guru sebagai fasilitator harus mampu menerapkan suasana belajar yang melibatkan siswa secara aktif dalam proses pembelajaran. Siswa akan aktif berada dalam pembelajaran yang bisa membuat siswa bisa melakukan aktivitas seperti berbicara, mengungkapkan pendapat, membaca, menulis dan saling berhubungan dengan siswa lain dan juga guru.

Jadi Seseorang dikatakan paham apabila ia mampu mengungkapkan kembali arti yang dipelajari, mampu memberikan kesimpulan dan menjelaskan baik secara lisan maupun tulisan. Media interaktif berbasis multimedia presentation dapat meningkatkan pemahaman konsep siswa, karena dengan media ini siswa diberi kesempatan berpikir mencari jawaban secara mandiri, guru sebagai fasilitator menyediakan media dengan menampilkan gambar-gambar (fakta) yang berhubungan dengan kehidupan sehari-hari yang ditampilkan dengan komputer atau laptop berkaitan dengan materi pelajaran, sedangkan yang menemukan konsep dari materi itu adalah siswa itu sendiri. Siswa membangun sendiri konsep di dalam pikirannya dan mampu mengaitkan dengan realitas yang ada di masyarakat.

\section{Kesimpulan}

Pembelajaran dengan menggunakan webquiz quizizz berpengaruh terhadap hasil belajar siswa khususnya pada materi masalah sosial pada pembelajaran sosiologi di kelas XI IPS 1 SMA N 16 Padang untuk materi pengertian masalah sosial, faktor pendorong masalah sosial, contoh masalah sosial dalam masyarakat, dampak masalah sosial dan pemecahan masalah sosial dalam masyarakat, hal ini dibuktikan dengan nilai t hitung $=6,34$ dengan taraf nyata 0,05 sedangkan tabel $=2,00$. Oleh karena $t$ hitung besar dari t tabel maka hipotesis penelitian diterima.

\section{Daftar Pustaka}

Azhar, A. (2011). Media Pembelajaran. Jakarta: PT. Grafindo Persada.

Darling-Hammond, L. (2014). Next Generation Assessment: Moving Beyond the Bubble Test to Support 21st Century Learning. San Fransisco: Jossey-Bass.

David A Payne. (1994). Designing Educational Project and Program Evaluations. New York: Springer Science Business Media.

Heinich, R. Molenda, M., Russell, J.D, Smaldino, S. E. (2002). Instructional Media and Technology For Learning (7 th Editi). New Jersey: Prentice Hall, Inc.

Lickona, T. (1991). Educating for Character: How Our School Can Teach Respect and Responsibility. New York: Random House Publishing Group.

Muhson, A. (2010). Pengembangan Media Pembelajaran Berbasis Teknologi Informasi. Jurnal

Pendidikan Akuntansi Indonesia, 8(2). https://doi.org/10.21831/jpai.v8i2.949

Putrawangsa, S., \& Hasanah, U. (2018). Integrasi Teknologi Digital Dalam Pembelajaran di Era

Jurnal Sikola: Jurnal Kajian Pendidikan dan Pembelajaran Vol. 2, No. 3, Th. 2021 
Industri 4.0. Jurnal Tatsqif. https://doi.org/10.20414/jtq.v16i1.203

RI, K. Permendikbud No. 21 Tahun 2016 tentang Standar Isi Pendidikan Dasar dan Menengah. , (2016).

Robert E. Slavin. (2006). Educational Psychology: Theory and Practice (8th ed). Boston: Pearson Education, Inc.

Santika, I. W. E. (2020). Pendidikan Karakter pada Pembelajaran Daring. Indonesian Values and Character Education Journal, 3(1), 8-19.

Santrock, J. W. (2011). Educational psychology (5th ed). New York: McGraw-Hill.

Sari, N. M., Erianjoni, E., \& Sylvia, I. (2019). Perilaku Siswa Menghadapi Ujian Nasional Berbasis Komputer di SMAN 3 Kota Pariaman Tahun 2018. Jurnal Perspektif, 2(1), 1-11. https://doi.org/10.24036/perspektif.v2i1.58

Slameto. (2010). Belajar dan Faktor-faktor yang Mempengaruhinya.

Sudjana, N. (2002). Penilaian dan Hasil Proses Belajar Mengajar. Bandung: Remaja Rosdakarya.

Sugiyono, S. (2008). Memahami Penelitian Kualitatif. Bandung: Alfabeta.

Susanti, F. D., \& Junaidi, J. (2020). Studi Evaluatif Penerapan Strategi Pembelajaran Sosiologi di SMA N 2 Pariaman. Jurnal Sikola: Jurnal Kajian Pendidikan Dan Pembelajaran, 1(3), 160167. https://doi.org/10.24036/sikola.v1i3.29

Sylvia, I., Anwar, S., \& Khairani, K. (2019). Pengembangan Instrumen Penilaian Autentik Berbasis Pendekatan Authentic Inquiry Learning Pada Mata Pelajaran Sosiologi di Sekolah Menengah Atas. Socius, 6(2), 103-120. https://doi.org/10.24036/scs.v6i2.162

Yusuf, A. M. (2015). Asesmen dan Evaluasi Pendidikan. Jakarta: Prenada Media Grup. 